\title{
Archaeological Testing of Site 41BU24 Burleson County, Texas
}

Wayne C. Young

Follow this and additional works at: https://scholarworks.sfasu.edu/ita

Part of the American Material Culture Commons, Archaeological Anthropology Commons, Environmental Studies Commons, Other American Studies Commons, Other Arts and Humanities Commons, Other History of Art, Architecture, and Archaeology Commons, and the United States History Commons

Tell us how this article helped you.

This Article is brought to you for free and open access by the Center for Regional Heritage Research at SFA ScholarWorks. It has been accepted for inclusion in Index of Texas Archaeology: Open Access Gray Literature from the Lone Star State by an authorized editor of SFA ScholarWorks. For more information, please contact cdsscholarworks@sfasu.edu. 


\section{Archaeological Testing of Site 41BU24 Burleson County, Texas}

\section{Licensing Statement}

This is a work produced for the Texas Department of Transportation (TxDOT) by the report producer. TxDOT and the report producer jointly own all rights, title, and interest in and to all intellectual property developed under TXDOT's contract with the report producer. The report may be cited and brief passages from this publication may be reproduced without permission provided that credit is given to both TxDOT and the report producer. Permission to reprint an entire chapter, section, figures or tables must be obtained in advance from either the Supervisor of the Archeological Studies Branch, Environmental Affairs Division, Texas Department of Transportation, 125 East 11th Street, Austin, Texas, 78701 or from the report producer. 
ARCHAEOLOGICAL TESTING OF SITE 41BU24

BURLESON COUNTY, TEXAS

\author{
B y \\ Wayne C. Young
}

Texas

State Department of Highways and Public Transportation

Highway Design Division

March 1985

\title{
ARCHAEOLOGY LIBRARY
}




\begin{abstract}
Testing of Site 41BU24 on State Highway 36 in Burleson County, Texas, to determine eligibility for inclusion within the National Register of Historic Places and to determine site depth, cultural context, and archaeological signbficance, was undertaken in January 1985. The site is located on a ridge overlooking Yegua Creek and extends into the creek floodplain. It has been heavily impacted by previous construction activities and the exact site limit is difficult to determine. Results of testing indicate that Site 41BU24 contains a minimal prehistoric component of unknown age which is thoroughly mixed with modern debris. Evidence recovered does not support a determination of eligibility for inclusion within the National Register of Historic Places.
\end{abstract}




\section{INTRODUCTION}

Archaeological Site 41BU24 was recorded at the Texas Archeological Research Laboratory of the Balcones Research Center, The University of Texas at Austin, in July 1981 by a member of the State Department of Highways and Public Transportation (SDHPT) professional cultural resources staff.

Following initial evaluation, further investigation and testing were recomended. During the period of January 21 and 22, 1985, testing operation\$ were conducted by Wayne C. Young of the SDHPT professional cultural resources staff with field support personnel provided by the SDHPT District 17 Brenham Residency Office.

Testing of Site 41BU24 was performed under the auspices of Procedures for the Protection of Historic and Cultural Properties (36 CFR, Part 800), procedures prescribed and endorsed by the Federal Highway Administration. The object of the test was to determine eligibility for inclusion of the site within the National Register of Historic Places as prescribed by Federal regulation and to determine the nature of the deposits and the cultural context of the site.

The highway construction project affecting Site 41BU24 provides for the construction of a four-lane railroad grade separation structure over the AT\&SF Railroad on State Highway 36. The existing facility is a two-lane roadway with surfaced shoulders changing to a $50 \mathrm{ft}$. wide curb and gutter section in Somerville. Additional right-of-way will be required to allow for aslight relocation of the grade separation structure in order to improve alignment and to increase the roadway width through the structure.

Site 41BU24 is located about $1 \mathrm{mile}$ south of the community of Somerville on \$1 36 (Fig. 1). The site originally extended on both sides of the highway on the northeast bank and terrace of Yegua Creek. The soil consist $\$$ of an unconsolidated brown sand with underlying sterile red clay. A portion of the terrace has a flint and chert gravel cap. The site deposits have been significantly disturbed by previous construction and other activities. 


\section{This Page Redacted Per THC Policy}




\section{SITE DESCRIPTION}

Site 41BU24 originally may have covered some 2 or more acres along a hilltop overlooking the Yegua Creek floodplain. It has been heavily impacted by previous construction activities and the exact 1 imit is now difficult to define. The site appears to have covered the top of a prominent hilltop or ridge and may have extended down into the Yegua Creek floodplain. Presently the hill is about $60 \mathrm{ft}$. higher than the creek and rises very rapidly from the floodplain.

The present route of $\mathbf{S H} \mathbf{3 6}$ bisects the site on a scuthwest to northeast axis, with the present roadbed excavated to a $25 \mathrm{ft}$. deep cut through the hill. The raod and adjacent backslopes have eliminated about onethird of the site and the hill itself (Fig. 2). A railroad bed for the AT\&SF Railroad crosses the site from northwest to southeast and also has impacted a major portion of it. A significant portion of the site was removed with the construction of the railroad roadbed.

The southwest quadrant of the site (south of the highway and west of the railraod) has been largely destroyed. An old county roadside park/picnic area is located here and a significant amount of fill was removed to level the areafor this construction. This area is outside of the SH 36 rightof-way and will not be affected by the project.

The southeast quadrant (south of the highway and east of the railroad) is also outside of the right-of-way and has been heavily eroded, with little chance of materials remaining in their original cultural context. This area contains the most visible cultural material as determined from surface observations, but since it lies outside of the right-of-way, it will not be affected by the project.

The northeast quadrant (north of the highway, east of the railroad, and south of a county road) also has been destroyed. That portion of the site within this quadrant has been used as a borrow source and no cultural material was visible on the borrow pit floor. In this area it would appear that all deposits containing cultural material have been quarried and removed at some time in the past. 


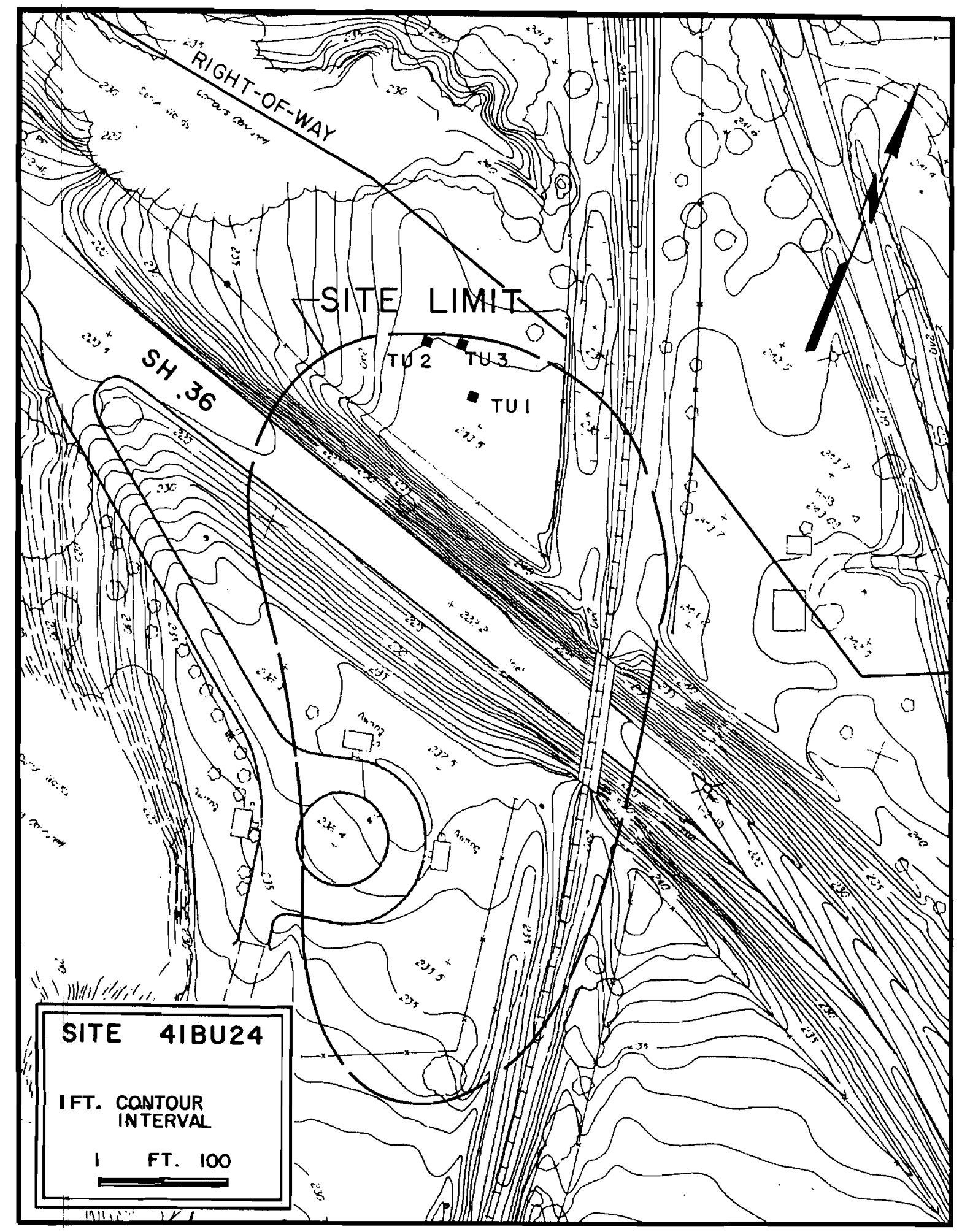

FIGURE 2. Project area showing estimated limit of Site $41 B U 24$ and location of test units. 
The northwest quadrant (north of the highway and west of the railroad) is hhe only semi-intact portion of $41 B U 24$ within the highway right-of-way. This area appears to have been plowed for many years, leaving berms around the fences. This portion of the site is also undergoing active bioturbation. The western half of this quadrant is located on a steep slope and appears to be highly eroded. There is an area of some 30 by 30 meters on top of the hill which represents the most intact area of the site. Testing activities were concentrated in this area. 


\section{TESTING OPERATIONS}

Archaeological testing of Site 41BU24 consisted of surface observations and the excavation of test units by hand (Fig. 2). Testing operations were concentrated in the northwestern quadrant as defined above. This is the only area of the site within the highway right-of-way which possibly contained intact cultural materials, although even this was by no means certain. Three 1 by 1 meter test units were excavated by hand (Fig. 2). Vertical control was maintained in 10 am arbitrary levels from the existing ground surface. Shovels and trowels were used to remove the soil and a 11 matrix was passed through 0.25 in. hardware cloth screens. All material recovered was bagged and labeled by test unit and level coordinates and was removed from the site for analysis and temporary storage at the SDHPT Laboratory for Archaeological Studies.

Excavation unit placement was arbitrary since no concentration of cultural material was visible on the surface. Test Unit 1 was placed on the highest part of the hill, Test Unit 2 was placed very near the steep slope, and Test Unit 3 was placed near the northern limit of the right-of-way (Fig. 2).

Test Unit 1 was excavated to a depth of $60 \mathrm{~cm}$, at which point a sterile red clay was encountered underlying a brown unconsolidated sand. Level 1 produced 5 wire $n$ ails and 1 bailing wire fragment. Level 1 contained 4 wire nails and a wire fragment. Levels 3 to 6 were culturally sterile.

Test Unit 2 was excavated to a depth of $40 \mathrm{~cm}$, where the sterile red clay was encountered. Level 1 contained 1 flake, 2 wire nails, 5 clear glass fragments, 1 saucer fragment, and 1 crockery fragment. Level 2 produced 2 wire nails, 1 clear glass sherd, 1 purple glass sherd, and a bottle neck. Levels 3 and 4 were culturally sterile.

Test Unit 3 was excavated to a depth of $30 \mathrm{~cm}$. Level 1 contained 9 wire nails, 1 mussel shell fragment, 38 clear glass sherds, 3 amber glass sherds, 3 sherds from a plain white plate, and 1 blue enamaled earthenware 
fragment. Level 2 yielded 9 wire nails, 1 fence staple, 4 white earthenware sherds, a .22 caliber short shell, and $\mathbf{3 3}$ fragments of clear glass. Level 3 was sterile. At this point a sterile red clay was encountered.

A detailed surface examination of this quadrant of the site yielded only 2 flakes and a possible mano fragment from the heavily eroded back-slope. The difficulty of examining the surface was compounded by a dense growth of big bluestem and dewberry bushes. However, numerous gopher mounds were observed in this quadrant and these provided good visibility. o cultural material was observed associated with these gopher mounds.

Testing results indicate a maximum depth of 20 am for the site. This depth wound fall within the suspected plow zone. Prehistoric material, represented by only 3 flakes, 1 from a test unit and 2 observed on the surface, and a possible mano fragment from the surface, was very sparse and was thoroughly intermixed with twentieth century historic materials. 
Archaeological testing of Site 41BU24 has established that the site has been largely destroyed by past construction activity including previous highway construction, railraod construction, the establishment of a county roadside park/picnic area, and borrow-pit excavations.

That portion of the site still extant contains minimal evidence of a prehistoric occupation of unknown age which is thoroughly mixed in a possfble plow zone with modern cultural debris. Cultural remains in this area have also been subject to disturbance due to erosion and bioturbation including intensive gopher activity. The lack of cultural context and the extreme sparsity of prehistoric materials recovered or observed negate the need for additional investigation at the site.

It is believed that the portion of Site 41BU24 within the highway rightof-way does not meet the criteria for inclusion within the National Register of Historic Places. No further investigation at Site 41BU24 is recommended. 